\title{
EVIDENCES OF QUATERNARY PALEOSEISMICITY IN HYDROMAGMATICS DEPOSITS IN THE CAMPO DE CALATRAVA VOLCANIC REGION (CENTRAL SPAIN)
}

\author{
Elena González \\ Rafael U. Gosálvez \\ Rafael Becerra \\ Estela Escobar \\ Departamento de Geografía y Ordenación del Territorio. Universidad de Castilla-La Mancha \\ Elena.Gonzalez@uclm.es, RafaelU.Gosalvez@uclm.es, Rafael.Becerra@uclm.es, Estela.Escobar@uclm.es
}

\begin{abstract}
Paleoseismicity is an indispensable tool in calculating seismic hazards in that what provide information in time periods that can span the entire Holocene. The aim of this paper is to present a series of records of liquefaction-fluidization generated during the Quaternary in sediments linked to hydromagmatic events in the Campo de Calatrava. Three types of deformation structures have been recognized that can be interpreted as seismites: microfaults, rolling distorted and pilars. The knowledge of the seismic hazard and the induced effects are essential in the land planning.
\end{abstract}

Key words: Pyroclastic density currents deposits, hydrovolcanism, seismic events, Quaternary, Campo de Calatrava, Spain.

\section{RESUMEN}

La paleosismicidad es una herramienta indispensable en el cálculo del riesgo sísmico, proporcionándonos información a lo largo de todo el Holoceno. El objetivo de este trabajo es dar a conocer la existencia de registros de licuefacción-fluidización de edad cuaternaria

Fecha de recepción: noviembre 2011.

Fecha de aceptación: enero 2013. 
en depósitos vinculados a erupciones hidromagmáticas en el Campo de Calatrava. Se han reconocido tres tipos de estructuras de deformación que pueden considerarse como sismitas: microfallas, laminación distorsionada y pilares. Conocer el riesgo sísmico y sus efectos inducidos es esencial en la ordenación del territorio.

Palabras clave: Flujos piroclásticos, hidrovolcanismo, eventos sísmicos, Cuaternario, Campo de Calatrava, España.

\section{INTRODUCTION}

In architecture and civil engineering many geotechnical and dynamic aspects need auxiliary sciences among which is the Geomorphology, in order to anticipate and reduce the natural hazards that can affect buildings and basic infrastructure as: dams; communication; water, gas and electricity distribution networks; airports, highways and rail. Within the various disciplines that make up the geomorphology the study of the paleoseismicity is an indispensable tool in the seismic hazard calculations because the instrumental and historical records not cover more than 1500 years. This discipline can provide information in time periods that can span the entire Holocene (Rodríguez-Pascua, 2007). The objective of the paleoseismicity is to recognize and identify paleoseismic evidences that some authors (McCalpin, 1996; González-Vallejo, 2004 y Carmona et al., 2011) classified in: first order, ruptures coseismic in superficial faults; second order, evidence generated on the surface during the earthquake (Liquefaction and fluidization processes recognizable in the field by seismites) and third order, terrain modelling after seismic event (triangular facets, conditioning of the river network, etc.).

The Iberian Peninsula is located in the collision zone of the Eurasian and African plates. The displacement between the two continents is responsible for seismic activity in the Mediterranean. Spain is not an area of occurrence of large earthquakes, but it has a significant seismic activity with earthquakes of magnitudes near to 7.0 degrees, excepting those that occurred in the Azores-Gibraltar fault (earthquakes of 1755 and 1969) but capable of generating severe damage. Annually in the Iberian Peninsula are registered between 1200 and 1400 earthquakes mostly with a magnitude less than 3 degrees on the Richter ML scale (DGPCE, 2012).

The aim of this paper is to present a series of records of liquefaction-fluidization generated by large earthquakes during the Quaternary in unconsolidated sediments linked to hydromagmatic events in the Campo de Calatrava volcanic region (CCVR) of which no record has been instrumental or historical. This seismic activity should be considered to comply with earthquake-resistant building standards and a basic planning guidelines and civil protection to the seismic risk in this volcanic region.

\section{STUDY AREA}

The Campo de Calatrava is a volcanic region located in Central Spain where some eruptive cycles of different intensity, spatial location and temporality along more than 8.My 
took place (Ancochea, 1983). This volcanism is associated with the Olot region (Cataluña), Central Massif (France) and the Eiffel region (Germany) joining all these volcanic regions in European continental intraplate volcanism (Cebriá \& López-Ruiz, 2010). Eruptions of this volcanic system derive from the rise of alkaline magmas rich in $\mathrm{CO} 2$, caused by a mantelic abnormality located at little depth under the region, without any development of the processes of magmatic differentiation of them (Ancochea, 1983). This has caused some eruptive events of low explosivity (Hawaiians and violent strombolian eruptions), characterized by the emission of pyroclastics fall and fluid lavas, building cinder cones, spatter cones and lava flow. The interaction of the magma with the subterranean or sub-superficial water has allowed the development of events of high explosivity (hydromagmatics) with formation of wide depressions (maars and tuff ring) and the development of pyroclastic density currents (base surge deposits, short lahars and mud flow deposits). More than 300 volcanic edifices which are laid out along more than $5.000 \mathrm{~km}^{2}$ have been identified.

The volcanic system of the Campo de Calatrava is characterized by the emission of basaltic magmas generated by partial melting progressive rates from a homogeneous mantle source (Cebriá \& López-Ruiz, 2010). These eruptions are developed lava fountains that generate large and powerful spatter formations.

Figure 1

DISTRIBUTION OF EUROPEAN ALKALINE VOLCANISM FROM CRETACEOUS TO CENOZOIC

(Oyarzum et al. 1997, simplied)

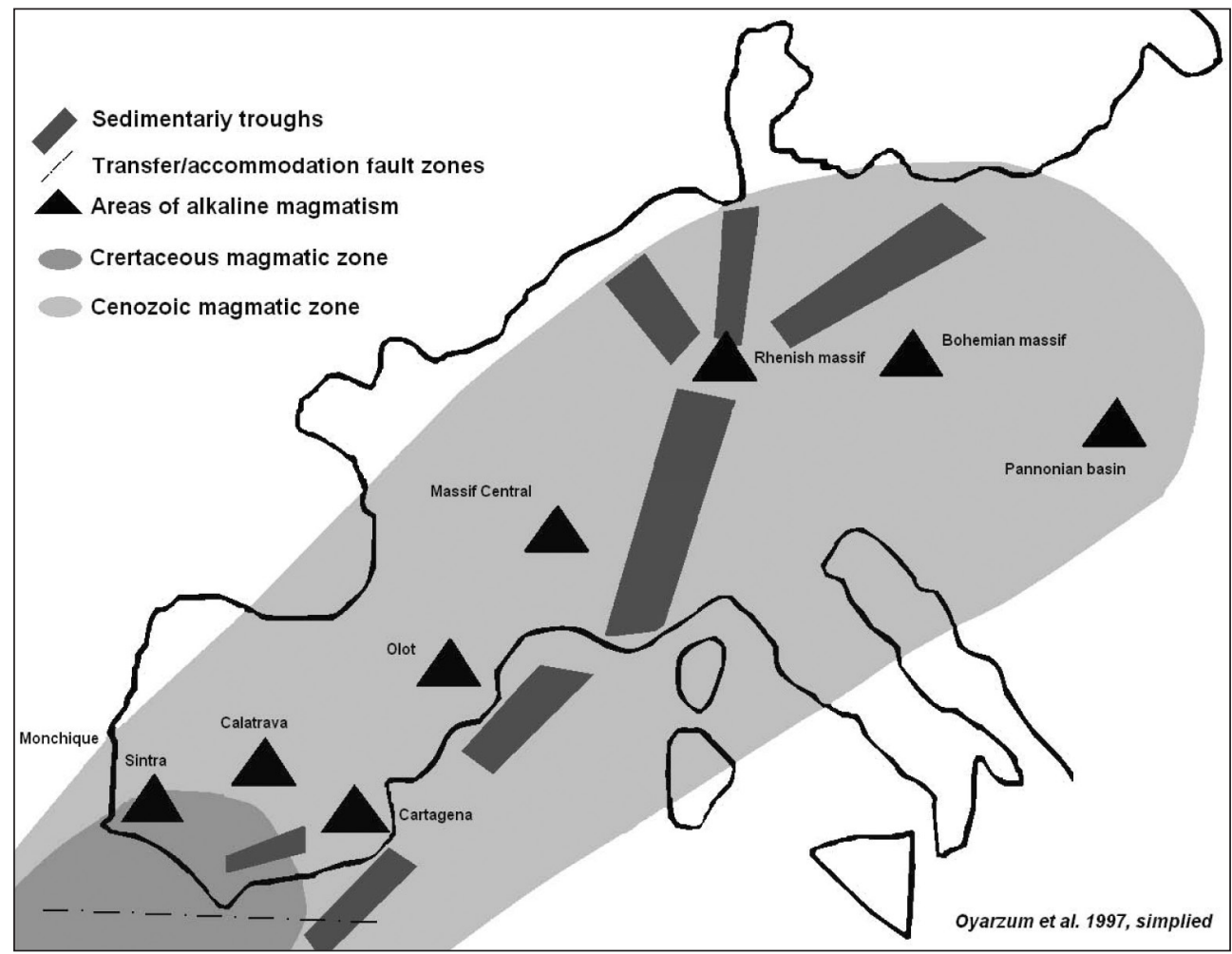


In the Campo de Calatrava for $8 \mathrm{My}$ (Mio-Pliocene) to the middle Holocene has developed an eruptive activity organized in cycles or stages separated by long periods of calm (Ancochea, 1983 y Poblete, 1994).

Recently, through radiometric dating of organic remains embedded in a paleosoil (González et al., 2007) have been able to confirm the existence of phreatomagmatic events whose deposits fossilize the paleosoil. This puts the last activity of Campo de Calatrava in the middle Holocene (absolute age 6560 and $6590 \mathrm{BP}$ ) and gives the status of potentially active volcanic region (Smithsonian, 2012).

At present there is a residual activity was characterized by diffuse emission of magmatic gas between predominantly $\mathrm{CO} 2$ whose origin could be an important degassing of a deep magmatic body, and its arrival to the surface be related to the fracture system affecting the paleozoic basement (Calvo et al., 2010).

\section{METHODS}

It has conducted a detailed analysis of nine deposits formed in phreatomagmatic eruptions, which has been made possible by the same courts that have occurred as a result of the recent construction of two highways that cross the volcanic region and the expansion of local roads.

Has been determined the nature of the deposit establishing the following parameters: nature, origin (location of the emission vent), thickness, surface area, granulometry and up and under formations. It has developed a mapping where they have established observation points in the context of the location of deposits.

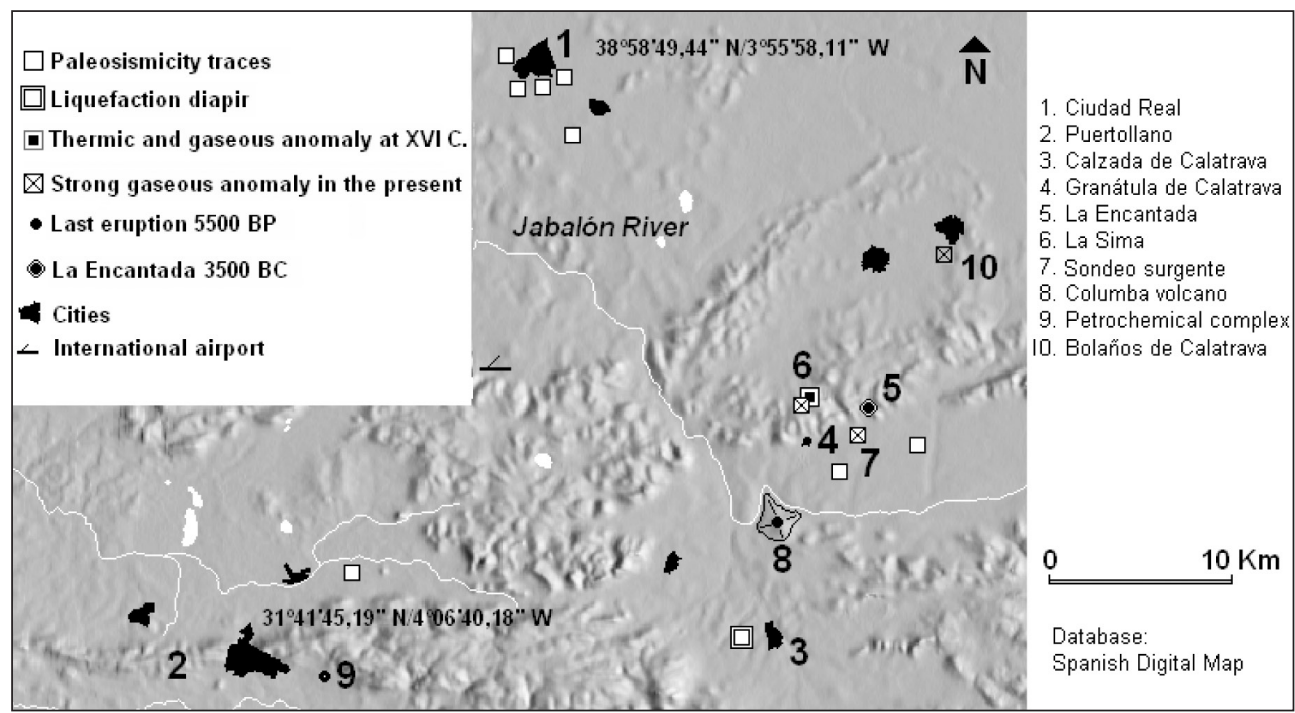


The pyroclastic flow deposits occupy large areas in the Campo de Calatrava. The locations in which it has carried out the study are located at south and east of Ciudad Real, it is here where you have located the seismic deformation (Fig. 2).

The study area is covered by larges thickness of pyroclastic density currents deposits (base surge and mud flow) that have well over carbonated and limestone sedimentary materials constituting the basin fill fine ash and lapilli on Pleistocene eruptions.

The points which have carried out research work shown in Fig. 2, and are located under the town of Ciudad Real, throughout the southern and south eastern, between this town, the Calatrava Massif and Sierra de La Atalaya.

Three types of deformation structures have been recognized that can be interpreted as seismites (Alfaro et al., 1995): micro-faults, small vertical faults, normal and inverse, with millimeters and centimeters jump that form a dense network, forming conjugated systems and sealed by overlying levels, that have been interpreted as the result of seismic shocks (González et al., 2010); rolling distorted, irregular shape deformations that alter the primary mill of the sediment and are sealed by undeformed levels genetically related to liquefaction and fluidization triggered by large earthquakes, and pilars, escape structures of liquefactfluidized sediment which through the original rolling of the higher levels which are also related to large earthquakes.

\section{RESULTS AND DISCUSSION}

\section{Hydromagmatics dynamics and pyroclastic flow deposits}

In Campo de Calatrava, the lands forms derived from the hydrovolcanic activity are conditioned as by the water location which interacts with the magma and the strength of the materials over the explosion is developed. Presence of geothermal systems or magma docks which don't outcrop to the surface, it has determined an important phreatic activity which forms differ from the derived ones of the phreatomagmatic activity. Maars are the most widespread morphologies in Campo de Calatrava, characterized by the presence of an explosive depression opened under the pre-eruptive topographic surface. In the hard and fragile rocks of the hercynian base, the craters present very craggy and rough internal walls, with drops up to $150 \mathrm{~m}$. They usually lacks tuff ring and if they have they are incomplete when channelling the pyroclastic flows by paleovalleys. The open craters in sedimentary basins are subcircular or subelliptic, and they are surrounded by well defined tuff rings.

The phreatic and phreatomagmatic crisis are accompanied of the emission of explosive breccias and pyroclastic density currents deposits (pyroclastic flow, lahars and mud flow). In the central area of the volcanic region has produced the largest numbers of phreatomagmatic events in two areas of the major concentration: Ciudad Real and Jabalón river basin, and Calatrava Massif.

The deposits formed in phreatomagmatic eruptions occupy large areas in the region. Are well interstratified with carbonate sediments and pyroclastic fall deposits that fill the basins, well as the final deposition that overlaps any other, and only are affected by the current soil formation. Occasionally, these deposits are located on paleosoil dated as intra Holocene 
(González et al., 2010; Poblete y Ruiz, 2010), allowing you to date them as pyroclastic flow deposits recently.

About the Campo de Calatrava the $50 \%$ of the volcanic edifices have been generated in phreatic and/or phreatomagmatic eruptions. It has also been the existence of phases hydromagmatics in purely magmatic volcanoes. In the majority of deposits no items found to allow absolute dating, having been made relative dating when compared with other forms or formations of known age. The vast majority of these deposits belong to Pleistocene. This gives them an age between 2,500,000 and 10,000 years.

Pyroclastic deposits have different bed forms derived from the humidity level present in the flow at the time of emplacement, predominantly structures massive and planar and occasionally, corresponding to high energy flows, have been observed the formation of dunes and antidune.

\section{Deformation of seismic origin observed in the hydromagmatics deposits}

Where the seismic energy and material characteristics affected permit, have developed the typical forms (ridges and microfault) corresponding to liquefaction ranging from the formation of seismites to large diapirs of basin material (Lowe, 1976) drilling the entire deposit of the tuff ring. The possible seismic origin of these deformations (Montenat, 1993) is proved by the formations situated under and occasionally on deposits of pyroclastic flows who have not experienced any change, maintaining its horizontal position (Fig. 3, a-b).

The forms generated by liquefaction are especially intense in the flow deposits located between Ciudad Real-Miguelturra (Fig. 4 and 5), Pozuelo de Calatrava and in Granátula de Calatrava basin where there are localized large and intense liquefaction processes into tuff ring of Granatula maar (Fig. 6) and occasionally strong interference in the pyroclastic fall of «Boca del Campo» volcano (Fig. 7).

Figure 3, a-b

SEISMITES AROUND OF CIUDAD REAL (A) AND PETROCHEMICAL COMPLEX

IN PUERTOLLANO (B)

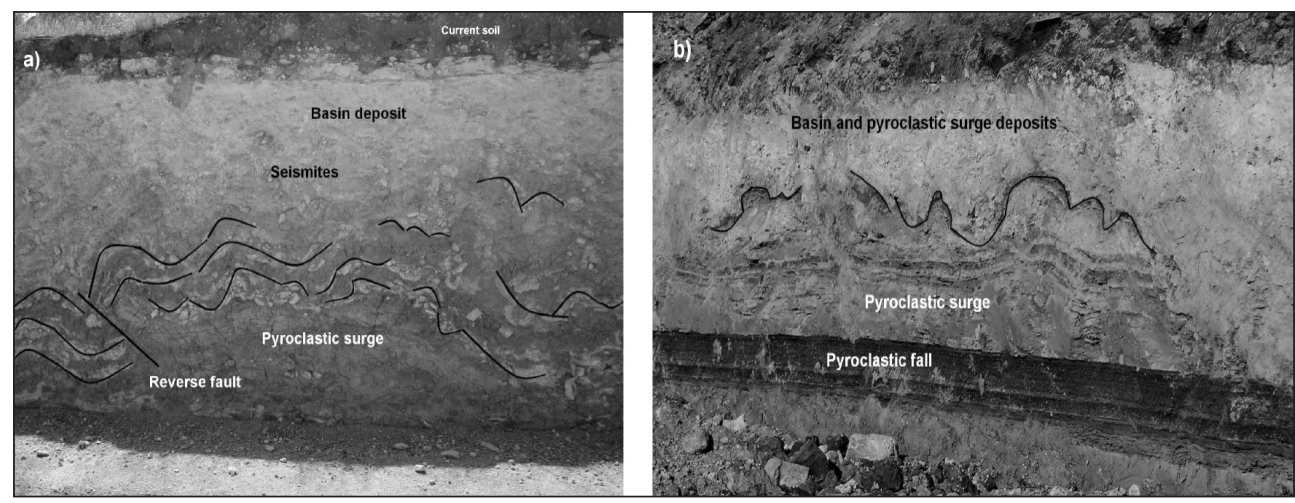


Figure 4

PYROCLASTIC FLOW QUATERNARIES DEPOSITS AFFECTED FOR EARTHQUAKE (SOUTH OF CIUDAD REAL)

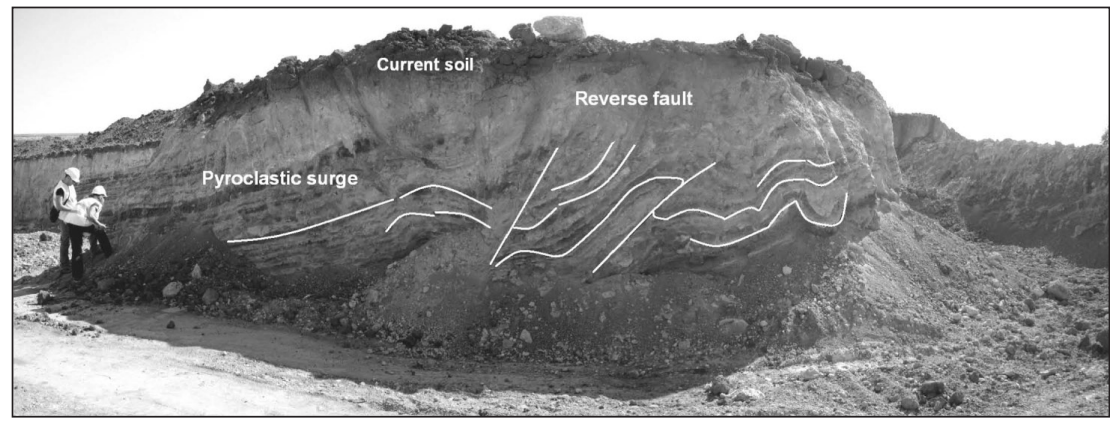

Figure 5

QUATERNARIES PYROCLASTIC DEPOSITS AFFECTED FOR SEISMIC DEFORMATION (SOUTH OF CIUDAD REAL)

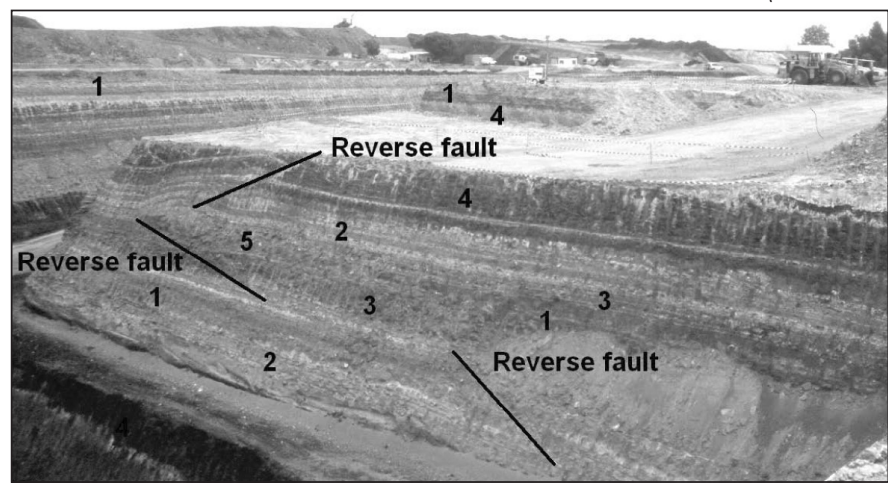

1) Pyroclastic fall, 2) Pyroclastic surge, 3) Basin deposit, 4) Paleosoil, 5) Liquefaction level

Figure 6

SEISMITE INTO TUFF RING OF GRANÁTULA MAAR

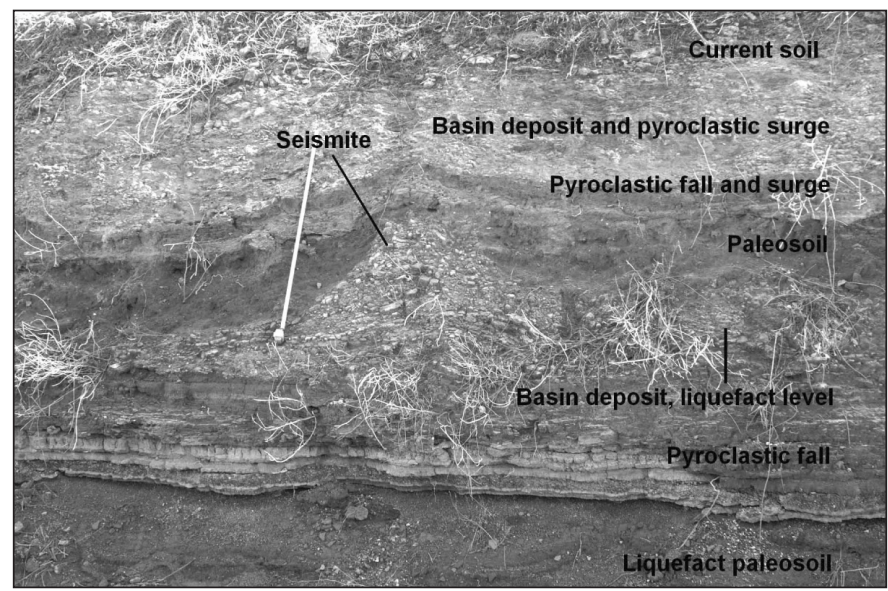


Figure 7

SEISMIC SIGNALS ON THE SLOPES OF «BOCA DEL CAMPO»VOLCANO

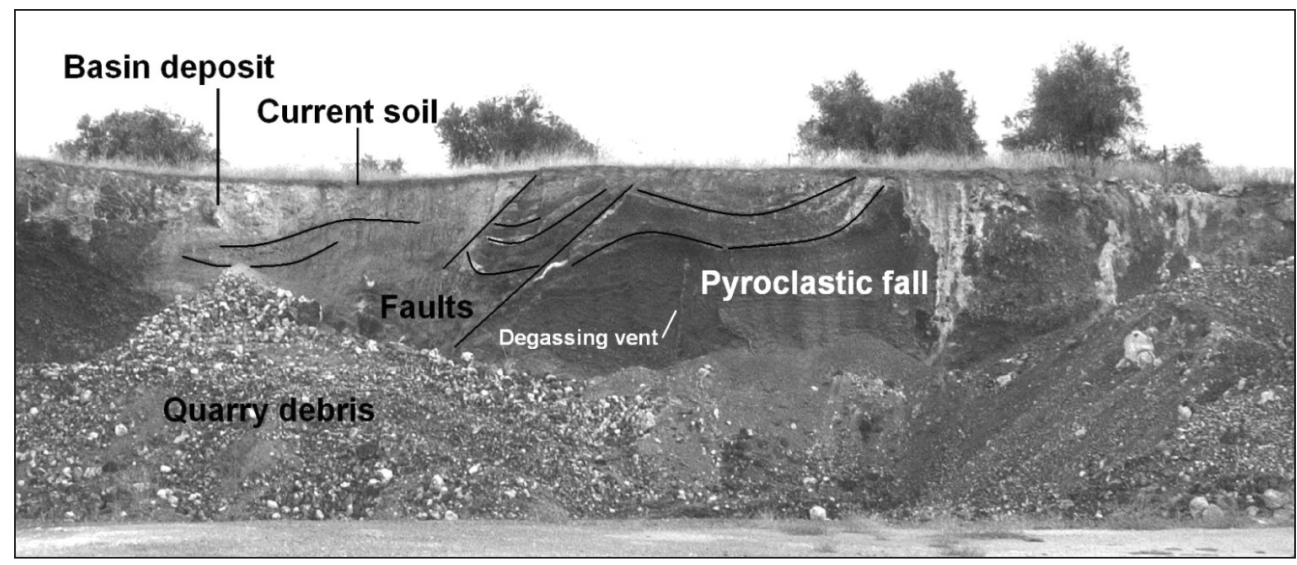

\section{Intense seismic processes: Liquefaction diapirs in Calzada de Calatrava}

The studied deposits are located in Calzada de Calatrava, at south of the volcanic region. Following a phreatomagmatic eruption of Pleistocene age, base surges generated give rise to a deposit type tuff ring of about 200 meters long visible, crossed by sand and silt which we interpret as arising from liquefaction of materials beneath the surges deposits. These deposits are arranged in a formation of carbonate material which, together with the current floor, the roof of recent contribution to the basin fill.

The bases surges have a direction $40^{\circ} \mathrm{N}$ and dipping $25^{\circ}$ that is progressively altered by intense dislocation, ending at the distal leg with dips of about $5^{\circ}$ and unaltered from its original position (Fig. 8, a-b). The outcrop presents rhythmic sequences of phreatomagmatic explosives pulses. Four major waves are observed that give rise to deposits of $60 \mathrm{~cm}$ of average thickness with a massive bedform, bordered by bands of ash extremely thin and compact. Above these deposits are located similar but much less thickness would correspond to rapid and sustained high energy explosive pulses. From this point the depot to be affected by faults and tilting reaching its layers and sink some sections.

Figure 8, a-b

DEPOSITS IN ITS ORIGINAL POSITIO (a) AND UPRIGHT AND COLLAPSED (b)
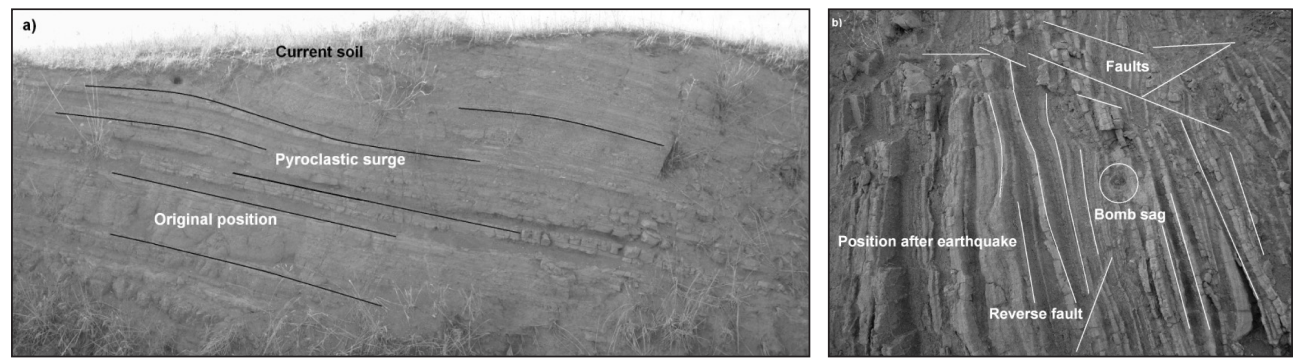
The base surge deposits contacted abruptly with a sandy material in four different points. This material passes through, up, distorts and breaks, verticalizes and promptly causes its partial collapse (Fig. 9). We interpret these intrusions as the result of a liquefaction process associated with an earthquake. The four intrusions have similar morphology and dimensions. Effect liquefaction boost to surface water jets and basin material (sand and silt) with a pressure capable of rupturing surges deposit. The output of this material causes partial vacuum inducing their collapse and the inclination of the layers to place them vertically. In the contact of the base surge deposits and liquefaction diapirs are located bands of muddy material, carbonates and evaporites. Marked trawl marks can be seen. Material liquefact is part of the lacustrine deposits that form large sedimentary basin where liquefaction occurs. It is composed of fine gravel, sand and silt (Table 1).

Figure 9

LIQUEFACTION DIAPIR BREAKING THE BASE SURGE DEPOSITS.

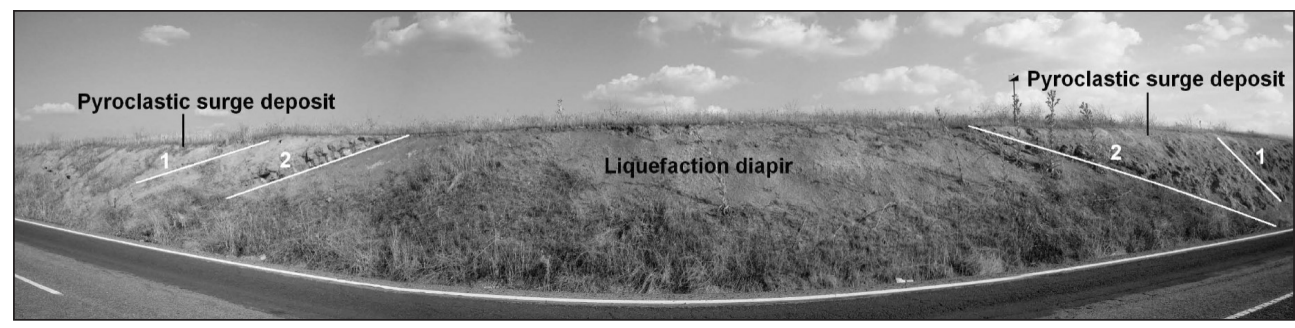

1) Tilt of the layer, 2) Contact of layer.

Table 1

GRANULOMETRY OF LIQUEFACT MATERIAL

\begin{tabular}{|l|c|}
\hline \multicolumn{1}{|c|}{ Material } & $\%$ \\
\hline Fine gravel & 10.00 \\
\hline Gross and medium sand & 77.04 \\
\hline Fine and very fine sand & 11.66 \\
\hline Gross and medium silt & 1.30 \\
\hline
\end{tabular}

\section{Hazards: earthquakes and magmatic gas emission}

The latest eruptions in Campo Calatrava occur in the middle Holocene (González et al., 2008), makes the area potentially active, and have a hydromagmatic character. Deposits of these events cover hundreds of $\mathrm{km}^{2}$ centered under urban areas they most dynamic and fastest growing population (150.000 peoples).

Recently have been found the existence of significant seismic events (7.5 degrees of Richter graduation) affecting these deposits (Rodríguez \& Barrera, 2002). The traces of this paleoseismicity (Pleistocene-Holocene) have been located in many areas of the volcanic region, with appreciable effect of liquefaction (González et al., 2010). Cities of Bronce 
Ibérico as «La Encantada» (3500 BC) have damage caused by earthquakes (GarcíaMeseguer, oral communication).

If there were an seismic event, volcanic or volcanic-seismic as those carried out in the recent Quaternary, in the same areas, the effects would be very dangerous in the biggest cities -Ciudad Real and Puertollano- (Fig. 11, a-b) and have an impact on communications infrastructures (highways, AVE, railway and airport) and also on industrial areas of risk as the petrochemical complex in Puertollano.

\section{Figure $11 a-b$}

\section{LIQUEFACTION EFFECTS UNDER CIUDAD REAL}
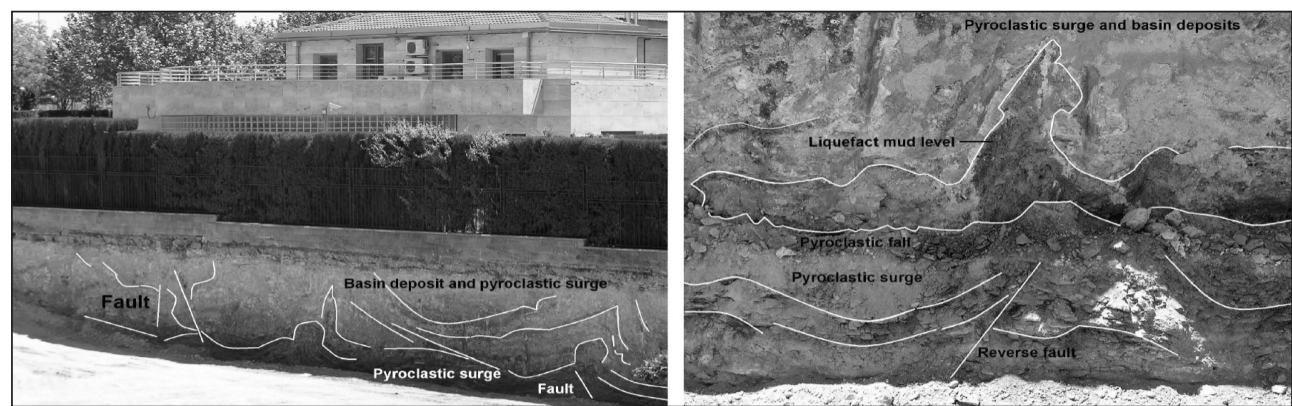

The Hercynian basement faults which affect the eastern boundary of the Campo de Calatrava show some degree of activity. There is an area of low seismicity where earthquakes are recorded with intensity between 1.5 and 2.5 degrees in the Richter scale. With long periods of recurrence (thousands of years) can be recorded earthquakes of higher intensity as

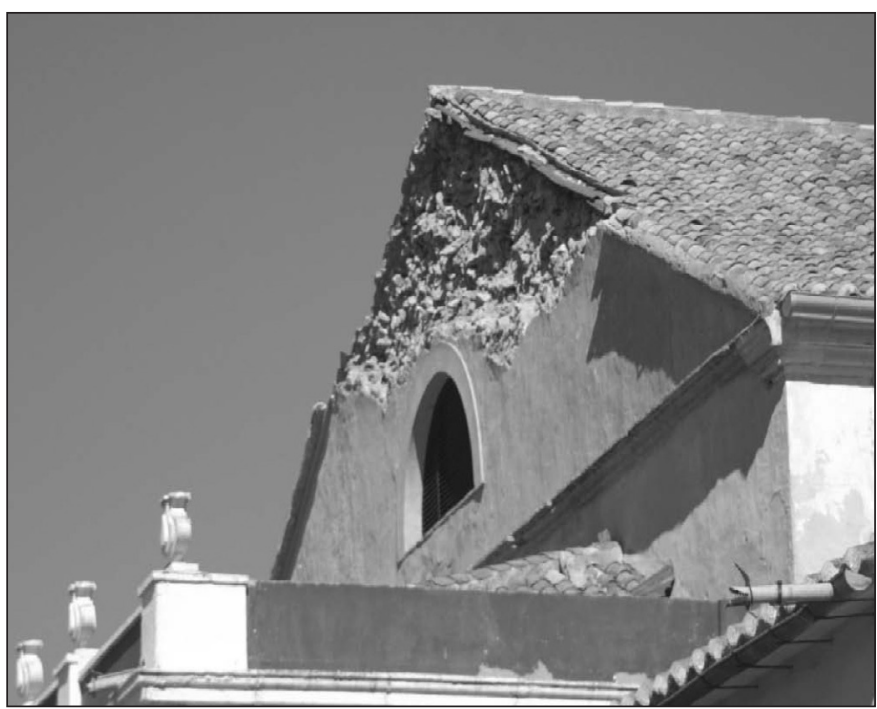


that produced august 12 of 2007 (5.1 degrees LM, $6 \mathrm{~km}$ depth, and 11 seconds long) (IGN, 2012). This earthquake was perceived over large areas of the central and south of the Iberian Peninsula, caused cracks in buildings places near of the epicenter, and the collapse of the roof and major damage to walls of the Municipal Theatre of Almagro.

Also affected the fracture that serve as emission vent for magmatic gas (CO2) and radon, resulting in a dramatic increase in the emissions of these gases especially noteworthy in de vents of La Sima volcano (Gosálvez et al., 2010). This vent is located on a fracture of direction NW/SE in a volcanic alignments area and semi-active eruptive fracture (Barrera, 2000).

This degassing vent has been continuous operation throughout the centuries, being described in historical documents of XVI century. Until the beginning of the summer of 2007 the emission of $\mathrm{CO} 2 \mathrm{had}$ values of $30,000 \mathrm{ppm}$. After the earthquake of that year, the values are more than a million of parts per million saturating the measuring instruments (Gosálvez et al., 2010).

In august 2007 researchers of Environment Division of ITER (Canary Islands), conducted a first evaluation of the diffuse emission of gases (project VOLATMCO2), which continued in 2008. The results highlighted the need to carry out continuous monitoring of gases that would evaluate in more detail its origin and value of emissions (Calvo et al., 2010).

In september 2007, a gas geochemistry field work was performed to evaluate the spatial distribution of $\mathrm{CO} 2$ efflux and estimate the total $\mathrm{CO} 2$ output from the three surveyed areas (Calvo et al., 2010). Results show the existence of an endogenous fraction in the CO2 emitted in a diffuse form. To do so, within the scope of the research project entitled: «Evaluation of the emission of $\mathrm{CO} 2$ in the volcanic system of the Campo de Calatrava, Spain. The gas vent of La Sima».

In may 2009 we proceeded with the installation, in the area that have been detected major gaseous emissions (vents of La Sima) of a geochemistry station in continuous mode for the detection of $\mathrm{CO} 2$ and $\mathrm{H} 2 \mathrm{~S}$. The increase in the emission of $\mathrm{CO} 2$ and radon, coincident with the detection of earthquakes located in areas close to the volcanic region, has led to the signing of a cooperation agreement between the University of Castilla-La Mancha (UCLM) and the National Geographic Institute (IGN) by which it is proceeding with the installation of a seismic network to detect in the area a possible microseismicity (Grupo de Volcanología IGN 2010 a y b). This will enable progress in the understanding of the current behaviour of the volcanic system of the Campo de Calatrava, and its relationship to other systems belonging to the European Intracontinental volcanism.

\section{CONCLUSIONS}

The phreatic and phreatomagmatic activity was very intense in the Campo de Calatrava throughout all periods of its eruptive history, with special emphasis on the Pleistocene. Major cities are located within maar or lie on the deposits of its eruptions, traces of paleoseismicity are found in many areas of volcanic deposits affecting those who identify traces of liquefaction. The last eruption of the Campo de Calatrava has an age of 5500 years minor (González et al., 2007). This eruption was a character pheatomagmatic with emission of multiple base surges. Phreatomagmatic events currently affect a large number of people and 
vital centres for the development of the territory. Quaternary seismic activity is a proven fact in many locations in the central and southeastern Spain affecting to fluvial and lacustrines sediments, while in the Campo de Calatrava are the pyroclastic flow deposits those who are affected by the seismic forces. The knowledge of the seismic hazard and the induced effects are essential in the territorial planning (Mulas de la Peña, 2008).

Recently spanish scientists, met in Guadalajara (Castilla-La Mancha) to determine the development new map of active faults in the Iberian Peninsula. Although there are no historical records of large earthquakes, if there is seismic deformation we speak of earthquakes of high magnitude with recurrence times of thousands of years, and therefore are not registered in the memory of the inhabitants of the affected regions.

\section{ACKNOWLEDGEMENTS}

This work was carried out within the Research Project: «Evaluation of the emission of CO2 in the volcanic system of the Campo de Calatrava, Spain. The gas vent of La Sima». Consejería de Educación y Ciencia JCCM. Fondos Europeos FEDER 2010-2012. We thank Carmen López Moreno, Director of Central Geodesic Observatory of the National Geographic Institute and their collaborators, and José Lorenzo Meseguer, their valuable contributions

\section{REFERENCES}

ALFARO, P., DOMENECH, C., ESTEVEZ, A. \& SORIA, J.M. (1995): «Estructuras de deformación en sedimentos del Cuaternario reciente de la cuenca del Bajo Segura (Alicante). Discusión sobre su posible origen sísmico». Geogaceta, 17:91-91.

ANCOCHEA, E. (1983): Evolución espacial y temporal del volcanismo reciente de España Central. Tesis Doctoral. Madrid, Universidad Complutense de Madrid.

CALVO, D., BARRANCO, J., PADILLA, G., BRITO, M., BECERRA-RAMÍREZ, R., GOSÁlVEZ, R., GONZÁlEZ, E., ESCOBAR, E., MELIÁN, G., NOLASCO, D., PADRÓN, E., MARRERO, R., HERNÁNEZ, P.A. \& PÉREZ, N. (2010): «Emisión difusa de $\mathrm{CO} 2$ en el Campo de Calatrava, Ciudad Real» en Aportaciones recientes en Volcanología, 2005-2008 (González et al., eds.). Almagro (Spain), Centro de Estudios Calatravos, 57-65.

CARMONA, J., ROMERO, C., DÓNIZ, J. \& GARCÍA, A. (2011): Characterization and facies analysis of the hydrovolcanic deposits of Montaña Pelada tuff ring: Tenerife, Canary Islands. Journal of African Earth Sciences, 59(1):41-50.

CEBRIÁ, J.M. \& LÓPEZ-RUIZ, J. (2010): «Modelos petrogenéticos y geodinámicos para el volcanismo del Campo de Calatrava» en Aportaciones recientes en Volcanología, 2005 2008 (González et al., eds.). Almagro (Spain), Centro de Estudios Calatravos, pp. 45-49

DGPCE (2012): Riesgos naturales: terremotos. Consultado el 1 de febrero de 2012, Dirección General de Protección Civil y Emergencias (DGPCE-Ministerio del Interior), website inforiesgos: http://www.inforiesgos.es/web/dgpcye/terremotos

GONZÁLEZ, E., GOSÁLVEZ, R.U., ESCOBAR, E. \& BECERRA, R. (2007): «Actividad eruptiva holocena en el Campo de Calatrava (volcán Columba, Ciudad Real, España)» en 
Contribuciones al estudio del periodo Cuaternario (Lario, J. \& Silva, P.G., eds.). Ávila (Spain), AEQUA, 143-144.

GONZÁLEZ, E., BECERRA, R., ESCOBAR, E. \& GOSÁLVEZ, R.U. (2010): «Evidencias de procesos de licuefacción afectando a depósitos de oleadas piroclásticas basales. Campo de Calatrava, España» en Avances de la Geomorfología en España 2008-2010, (Úbeda et al., eds.). Solsona (Spain), Centre Tecnològic Forestal de Catalunya, 381-385. GONZÁLEZ DE VALLEJO, L.I., TSIGE, M., \& CABRERA, L. (2004): «Paleoliquefaction features on Tenerife (Canary Islands) in Holocene sand deposits». Engineering geology, 76, 179-190.

GOSÁLVEZ, R.U., BECERRA-RAMÍREZ, R., GONZÁLEZ, E. \& ESCOBAR, E. (2010): «Evolución de la emisión de CO2 en La Sima. Campo de Calatrava (Ciudad Real, España) en Aportaciones recientes en Volcanología, 2005-2008 (González et al., eds.). Almagro (Spain), Centro de Estudios Calatravos, 101-103.

GRUPO DE VOLCANOLOGÍA IGN (2010 a): «Reducción del riesgo volcánico» en Aportaciones recientes en Volcanología, 2005-2008, (González et al., eds.). Almagro (Spain), Centro de Estudios Calatravos, 271-274.

GRUPO DE VOLCANOLOGÍA IGN (2010 b): «Sistema de vigilancia volcánica del IGN en tiempo real y campañas de densificación de datos» en Aportaciones recientes en Volcanología, 2005-2008 (González et al., eds.). Almagro (Spain), Centro de Estudios Calatravos, 275-278

IGN (2012): Servicio de Información Sísmica. Consultado el 21 de enero de 2012, Instituto Geográfico Nacional (IGN-Ministerio de Fomento), website: http://www.ign.es/ign/

layout/sismo.do

LOWE, D. R. (1976): «Subaqueous liquefied and fluidized sediment flows and their deposits». Sedimentology, 23:285-308.

McCALPIN, J.P. (1996): Paleoseismology. San Diego, Academic Press.

MONTENAT, C., D’ESTEVOU, P., BARRIER, P. \& PATUREL, D. (1993): «Les séismites, essai de typologie génétique». Geochronique, 46:15-17.

MULAS DE LA PEÑA, J. (2008): «Microzonación sísmica y ordenación del territorio» en El estudio y la gestión de los riesgos geológicos (Galindo, I. Laín, L. \& Llorente, M., eds.). Madrid, IGME, 107-120.

OYARZUM, R., DOBLAS, M., LÓPEZ-RUIZ, J. \& CEBRIÁ, J.M. (1997): «Opening of the central Atlantic and asymmetric mantle upwelling phenomena: Implications for longlived magmatism in western North Africa and Europe». Geology, 25:727-730.

POBLETE, M.A. (1994): El relieve volcánico del Campo de Calatrava (Ciudad Real). Asturias, Edición propia.

RODRÍGUEZ, M.A. \& BARRERA, J.L. (2002): «Estructuras paleosísmicas en depósitos hidromagmáticos del volcanismo neógeno del Campo de Calatrava, Ciudad Real (España)». Geogaceta, 32: 39-42.

RODRÍGUEZ-PASCUA, M.A. (2007): «Tema 20. Paleosismología: Terremotos, paleoterremotos y peligrosidad sísmica en España» en Cuaternario, cambio climático y peligros naturales asociados. Primer curso AEQUA sobre cuaternario (Silva, P.G. \& Bardají, T., coords.). Ávila (España), Universidad de Salamanca, 59-60. 
SMITHSONIAN INSTITUTION (2012): Global volcanism program: worldwide holocene volcano and eruption information. 01/15/2012 consulted, Smithsonian, National Museum of Natural History, website: http://www.volcano.si.edu/index.cfm. 